\title{
On the Panoptical Eye of Self-Caring in Nabokov's The Eye: A Foucauldian Analysis
}

\author{
Taghizadeh, Ali ${ }^{1} \&$ Haj'jari, Mohammad-Javad ${ }^{2}$ \\ 1,2 English Department, Faculty of Humanities, Razi University, Kermanshah, IRAN \\ *Correspondent author; Emails: altaghee@zedat.fu-berlin.de,_aminhajjari@gmail.com
}

\begin{abstract}
Nabokov's protagonist's sufferings, suicide, and final happiness in The Eye (1930) can be analyzed through Foucault's policy of the "care of the self" based on which an individual acts in a parrhesiastic relationship with himself to panoptically watch and discover himself. Smurov's first-person I/eye sacrifices his former self to be reborn from the surveying eyes of his separated self. This Panopticon metaphor is bifurcated into the monopticon and the synopticon, the former letting Smurov externally watch over himself and the latter reflecting back to him others' views of him. Thus, Smurov recognizes the true nature of his identity to be the sum of his concept of himself and his reflections in others' minds. He recognizes that he is always being panoptically watched and created. His final happiness, therefore, emphasizes that identity stands in a symbiotic relationship with the surveillance of the self, without which the individual stays in darkness.
\end{abstract}

Keywords: Care of the self; identity; Panopticon; Smurov; surveillance.

\section{INTRODUCTION}

Subjectivity, as Michel Foucault (1997) defines it, is what we make of ourselves when we are carrying out a project of self-care. Subjectivity is not what we are, but it is an activity that we perform, an active becoming. In a project of self-discovery, self-care, or self-expression, our interest is in the self. Thus, the "care of the self" is the meaning of the efforts we make to change ourselves to better persons or to specific individuals in order to answer the question "What should one do with oneself?" (p. 87) Such a project guarantees a freedom from the human primary self, but freedom from the primary self does not mean abandoning ourselves in order to become thoroughly new individuals. We in fact try to know the different aspects of our nature towards a comprehensive recognition of ourselves.

Taking care of one's self is partly suggested by the concept of the "Panopticon" in Foucault's philosophy, which conveys the surveillance and the control of the individuals by a few guardians through constant and evaluative observations for better individual and collaborative performances. Foucault elaborates on Jeremy Bentham's concept of the Panopticon in Discipline and Punish: The Birth of the Prison (1979). As Bentham's typical prison structure, the Panopticon is a system of surveillance in which a few individuals within a central tower constantly watch over a multitude of people, controlling and conducting their activities. As a watching system, the Panopticon establishes in its subjects the awareness that they are being constantly observed, and that they must watch themselves to behave according to certain norms. Likewise, an individual can make himself stand in a position so that he can watch himself and watch over his own behavior from the outside. Stepping outside one's own self to overlook the state of one's life resembles the observing capabilities that the Panopticon allows an observer, including the monoptic and the synoptic views on one's self. While the monoptic view derives from the individual looking at himself, the synoptic view radiates from others looking at him. The common element is to step outside oneself, which in Foucauldian terms, is a process of conversion for accessing the truth about one's self. It includes a break within the self, a kind of self-sacrifice, a sacrifice of one's old self in the name of truth for the sake of a more comprehensive view of the self. Truth is thus never bestowed upon the subject, for no truth exists without a "conversion" or a "transformation" of the subject. And truth, once accessed, "enlightens the subject" and leaves him in tranquility (Taylor, 2011, pp. 143-146).

This process of self-sacrifice is then completed through parrhesia, a practice that individuals should 
perform to attain their freedom. Foucault (2001) defines parrhesia as a free and courageous speech about the truth of something, and the parrhesiastes or the "parrhesiast" as the truth-teller, someone who knows and tells the truth. Knowing one's self is part of the truth. As such, the most important characteristic of the parrhesiast is his "honest counsel" to people or to himself against "self-delusion" and for a better recognition of the self (pp. 141-142). Accordingly, through the panoptic position, the individual tries to watch over himself in order to examine his behavior. In fact, an all-embracing outlook on one's own behavior reveals the truth about oneself and one's being. And this fact is inherent in the practice of parrhesia. Thus, the final purpose of parrhesia is selfidentification.

As a "semi-fantastic psychological novella" (Foster, 1993, p. 73), The Eye (1930) - Sogliadatai in Russian and meaning a "spy" or a "watcher" (The Eye,1990) highlights some of Nabokov's main thematic and structural concerns. As to the Foucauldian focus of the present study, the nature of identity and the most convenient state of happiness in the course of one's life-represented in the narrator's quest for "the real Smurov" (The Eye,1990) -seem to be two of Nabokov's important concerns in the book.

Smurov's identity crisis has been the subject of many interpretations, both thematically and structurally. Investigations into Smurov's state of being all share the fact that he is after his true identity, which he cannot finally achieve because of its dynamicity. Hence, his final adjustment to environmental changes constitutes a dynamic identity. These studies mostly elaborate upon Nabokov's own statement in the forward to the novella that the theme of the book is "the pursuit of an investigation which leads the protagonist through a hell of mirrors and ends in the merging of twin images" (Johnson, 1977, p. 1). Dean Flower (1987) analyzes the story and its references to the "eye/I" in highlighting Nabokov's own life and identity crisis, as he was a writer in self-exile. Accordingly, The Eye can be read "as a covert autobiography of the most self-condemning sort," and the entire story may be interpreted "as a howl of despair that he, Nabokov, does not really exist" (p. 167). Thus, Smurov embodies some chief aspects of Nabokov's own identity (p. 169). Boyd (1990) believes that Smurov's final failure highlights a certain point in human condition while he relates it to Nabokov's artistic life. Connolly (1991) investigates into the book's similarities with Dostoyevsky's The Double, and later takes Nabokov's narrator as overtly split into two agents, "narrator vs. observer" or "that aspect of the self which displays authorial potential and that aspect of the self which functions as a character" (p. 32). Johnson (1997) discusses "an emotionally detached, coldly observing "Eye/I"” as the narrator and "a new, more dashing" personality as Smurov who is "unaware of his dual identity", as someone who is both an observer and an observed ( $\mathrm{p}$. 2). Smurov establishes his existence through the "mirror reflections" radiated from other characters' "surface" (p. 169). In The Mind's Eye (2001), Karen Jacob discusses a number of elements in the novella, including narrativity, narcissism, and self-knowledge through the viewpoints of Descartes, Lacan, and Žižek. Regarding self-knowledge, she takes into consideration the hidden mechanisms of power that the "detached posture" of the realist narrator and his "panoptic eye" equip him with (p. 64). Jacob' emphasis is on the authorial narrator's "panoptic power" suggests that the narrator is "obsessively" attempting to have his doppelganger participate in the "fantasy of surveillance" to make sense of "the realist narrator's position" (pp. 52-53). She believes that the narrator's final failure spoils the parallelism between his own panoptic powers and those of the "institutions of discipline, regularization, and supervision" that narrative authority is thought to represent in realism (p. 74). Altogether she tries to know "how the subjectivized forms of viewing represented in The Eye inflect its treatment of surveillance as a narrative and possibly a social tool" (p. 71).

The concern of the present study is similar to what is under taken by Straumann, Jacobs, and Grishokova. However, it is basically different from them; the present study has tried to investigate into Smurov's condition through an interdisciplinary approach regarding Foucault's concept of the Panopticon and its relation to self-recognition. The researchers hope that their fascination with some of Foucault's termsthe "care of the self", parrhesia, and the Panopticon will help them delve deeply enough into Smurov's condition to show how he comes to a state of selfrecognition through a policy of self-denial.

Smurov's attempt at self-recognition incorporates a net of power relations, with himself and with others, which is always at work to constitute the condition of his own life as well as the life of any other man or woman. For the illumination of Smurov's conditions under Nabokov's panoptical eye, this article proposes a set of questions which it will attempt to answer: What is Smurov's real state of being? How is he experiencing life? At the end of the story, what is the nature of the pleasures which he thinks he is experiencing? 


\section{DISCUSSION}

Disgraced by Matilda's husband over adultery, Smurov feels utmost shame in front of the boys he tutors. This shame intensifies his former lighthearted thinking about suicide and the absurdity of the world. Thus, he shoots himself in the chest or over his heart, which leaves him lingering in a purgatorial imagination afterwards, if not in death and blankness. He then imagines that he has gained freedom of earthly suffering while he finds himself enclosed in bondages in a ward. He thus wonders saying, "What a mighty thing was human thought, that it could hurtle on beyond death!" He thinks that his thought is still running after his physical death. He still feels the "crater of a hollow tooth" and has no idea of any burial of his dead body. He succumbs to the present illusion by taking part in it actively. He further creates a doctor over his own "case of a light wound caused by an inaccurate bullet passing clean through the serratus."His "little old lady" also appears and informs him that a pitcher has also been smashed by the shooting. He thinks, "Oh, how cunningly, in what simple, everyday terms my thought explained the ringing and the gurgling that had accompanied me into nonexistence," which might indicate his subconscious level of recovery after the agony of shooting and anesthesia. In his imagination, he finds himself back to streets after his recovery. He thinks about his routines: fixing his smashed watch, getting cigarettes, money, etc. He then enters Weinstock's bookshop and befriends new people who reflect back different parts of his total identity to him. As Straumann (2008) says, not only does Smurov's "disembodied imagination survive," but in fact he divides himself into "a narrated figure and the eye/I that controls both narration and perception." And he goes on with watching the numerous masks of a personality, which finally turn out to be versions of himself and a world which is mostly the construction of his own imagination (p. 77).

Smurov's "solipsistic quest" (Wyllie, 2010, p. 76), which begins after his suicidal attempt and transformation into an "onlooker" (The Eye,1990), is an act of resistance or defense mechanism against his former self which he tries to overcome. In this act of overcoming, Smurov under goes a "spiritual experience", which is a specific surrealist experiment within which people let their bodies speak, as Foucault explains in his debate on the "new novel" and surrealist fiction (Vintges, 2011, p. 100). Characters in such novels go through experiences like "dreams, madness, folly, repetition, the double, the disruption of time, the return" which generate a coherent"constellation"of actions (Foucault,1999, p.
72). Such realms are the creations of "a radical critique of rationality" (Carrette, 2000, p. 56). Therefore, Foucault finds it intriguing to "think beyond the body/soul dualism of Western, Christian and Cartesian traditions" (Vintges, 2011, p. 100). He tries to make sense of a "spiritual corporality" and a "reordering of spiritual concepts into the body" (Carrette, 2000, p. 54). As such, the first-person narrative of the suicidal attempt by "a humiliated loser" generates "a psychologically plausible character of a narrator-as-ghost" who finally finds himself alive, while he is aware of the fact that he has experienced corporeal death (Dolinin, 2005, p.61). In such realms, the individual feels free to act unboundedly and thus develops a new life and outlook towards life. The narrator is then wondering how to answer his ontological questions regarding the "potential split between the subject and the world": "what is my relation to the world? How do I know that I exist? What if I am a ghost, a shade, a spook? What is the status of my imagination?" (Strauman, 2008, p. 77). Accordingly, stepping out of one's own self to overlook the state of one's life resembles the observing capabilities that the Panoptic on allows an observer. The remaining part of this article will attempt to elaborate on this issue.

\section{The Panoptic on Metaphor}

According to Foucault (1979), the Panoptic on is a great machine both for subjection and self-subjection. It induces in its subjects the awareness of their own constant visibility and thus enforces them to discipline their behavior according to its power mechanism. As such, the individuals are disciplined into a social range of behaviors which render them either normalized citizens or divergent ones. Smurov's identity crisis follows such problems of surveillance. The title of the novella and Smurov's wonderings highlight the fact that his problem is with the observing eye of himself and of others, which makes him behave in certain manners.

On the story level, the panoptical perspective reveals itself on two grounds: the monoptic and the synoptic; the former dealing with the narrator's interactions with Smurov, who is in fact himself, and the latter dealing with the narrator-Smurov's counteractions with other people.

\section{The Monopticon}

"Monoptic" means "with one eye" (Reber, 1985, p. 468). From this term, there comes "monopticons" which are kinds of security cameras in the form of android eyes. These were used by Monarch, a 
character in Doctor Who series, to control his subjects, specifically in the episodes entitled Four to Doomsday (1982). The monopticons consistently watched over individuals and scanned the munder Monarch's orders. One can suggest that they were the more advanced forms of Big Brother's telescreens in Orwell's 1984 which were constantly watching the citizens for surveillance. In $\mathrm{Dr}$. Who, the monopticons acted as "disembodied" heads and "intrusive" presences that were used to "spy on the action" of other characters. As such, the word monopticon is a play on the concept of the Panopticon (O'Day's, 2011).The monopticon thus refers to the control of an individual by another individual or by him/herself.

Having this concept in mind, one is tempted to consider Smurov's watchful eye over himself as such, a fact that is reflected in Nabokov's techniques of mirroring and doubling. Initially, the individual who watches over Smurov is himself, and we are concerned with his own surveying eye:

Yet I was always exposed, always wide-eyed; even in sleep I did not cease to watch over myself, understanding nothing of my existence, growing crazy at the thought of not being able to stop being aware of myself. (The Eye, 1990, Kindle)

We always find Smurov under his own observation, and he constantly and self-consciously watches over himself. It is as if his super ego is working on the conscious level and is always in charge of him. As such, he is simultaneously split into the subject and the object, one acting while the other recording those actions. This process is continued in the story until the subject and the object finally merge into one. Thus, we are subjected to two viewpoints of Smurov at the same time: a viewpoint of the observing narrator and a viewpoint of the Smurov who is being-observed. The narrator-Smurov has been there for stepping out his body and is able to "make judgments about his own actions" (Mohanu, 2001, p. 80). In such a "fantasy of disembodiment" (Toker, 1999, p. 97), Smurov begins to describe himself in the third person, since he has escaped the prison of his body. He is now concerned with "a centrifugally scattered self" (Jacobs, 2001, p. 76).The split of character that he is experiencing is an attempt at self-recognition, since stepping out of the subjective self is necessary to establish a disinterested image of it. Accordingly, Smurov watches over himself monoptically, as in a mirror-like encountering between himself and his image. Although a mirror reflects one's image without any presuppositions, Smurov discovers a nasty reflection of himself in it due to his concern with identity crisis:" A wretched, shivering, vulgar little man in a bowler hat stood in the center of the room, for some reason rubbing his hands. That is the glimpse I caught of myself in the mirror" (The Eye, 1990, Kindle). Changing that view toward the self requires self-disciplinary attitudes. Therefore, beginning "a new life" under the new role of being "an onlooker" intensifies the panoticon metaphor of the book. And it is necessary to hold that, as such, the panoticon and the monopticon become the same, for in this story the observer and the observed are the same.

\section{The Synopticon}

The self-observing Smurov also attempts to shape himself into a new form and away from his pathetic past, and as Connolly (1999) observes, to defend himself "against public opinion" as well (p. 145). This fact leads us to another play on the word Panopticon, that is, the synopticon which conveys the control of the minority by the majority or even the control of the individual by the many. It was first introduced by Thomas Mathieson (1997), who elaborated upon Foucault's argument about Bentham's Panopticon. Mathieson holds that through "the control of the soul, vis-à-vis the control of the body" a sort of human being is generated who behaves himself "through self-control" (p. 217). The former panoptic view regarding the surveillance of the majority by the few is now turned over on its head and changed into the surveillance of the minority by the majority as well as the individual by the people. And while the "normalizing gaze of panopticism" produces the subjectivity and the self-control which discipline people to fit into the society (p. 218), synopticism watches over the officials themselves. Synopticismis used to "represent the situation where a large number focuses on something in common which is condensed." It can act as the opposite of panopticism, and thus here the many watch the few. So each society becomes "a viewer society" (p. 219), in which panopticism and synopticism mostly merge into one observing standpoint. Mathieson takes Big Brother's telescreens as the ultimate form representing the fusion of panopticism and synopticism, as both Big Brother and people watch each other at the same time. Accordingly, the "intersecting gazes of panopticism," in Mathieson's terminology (p. 229), incorporate the simultaneous observing activities of both the involved parties. As such, Smurov's "Gestalts" in others' minds is significant (Grishakova, 2012, p. 170).

The problem with the narrator's panoptical watch over Smurov - as the narrator he invisibly watches over the physical Smurov- is that the ghost-narrator cannot discipline the physical Smurov until they merge into one. He tells Vanya that "actually I wear a 
mask - I am always hidden behind a mask" (The Eye,1990, Kindle). The hidden personality behind the mask acts as the monoptical, as a derivation of the panoptical, an observer who surveys "Smurovianmasks" (The Eye, 1990, Kindle). Here is a manifesttation of what Mathieson (1997) says regarding the fusion of the Panopticon and the synopticon, with the Panopticon bearing the concept of the monopticon too. Panopticism and synopticism have "developed an intimate interaction, even fusion, with each other." The same systems of surveillance have often been panoptical and synoptical simultaneously, as in the "Roman Catholic Church", "the Inquisition", and "the military", where there are both hidden individual puppeteers behind the scenes and apparent acting agents on the front (p. 223). The "Smurovian masks" are in fact the versions of Smurov that appear in the presence of others' observing eyes. And as they reflect back to Smurov's feedbacks about his identity, these reflections represent his Gestalts. Thus, the narrator says,

I could already count three versions of Smurov, while the original remained unknown. This occurs in scientific classification. Long ago, Linnaeus described a common species of butterfly, adding the laconic note "in pratis Westmanniae.". ...... Where is the type, the model, the original? (The Eye, 1990).

Here Johnson (1973) holds that since the narrator decides to establish "the real Smurov" as the sum of the reflections he evokes in others, he becomes an entomologist who studies the diversities of a specimen of insects to guess the original creature from which they descended. Each descendent might differ from its original form due to their present biological conditions, but they also have similarities with the original form and constitute the different parts of its intricatepuzzle. Accordingly, the narrator finds out that Smurov's images held by others or "collectors" vary in accordance with the "particular" contacts each of them has with him (pp. 2-3), as well as with "the climatic conditions prevailing in various souls" (The Eye, 1990, Kindle). It is then obligatory to know the others" in all of their secondary associations to assess their versions of Smurov [...] in order to establish [Smurov's] holotype" for his truest image (Johnson, 1997, p. 3). The narrator thus begins to pay attention to Smurov's versions in others' eyes. Vanya considers Smurov as "a good, intelligent person" with "poetic imagination", with a "propensity to exaggerate at times", as a man who is kind towards everyone, and as a guy who is "always absurd and charming." To Mukhin, Smurov is "such a scoundrel". Vanya's uncle's has "the happiest, the shortest-lived image of Smurov"; he thinks Smurov is their future bride- groom. Smurov is a criminal to be punished right away before his two pupils. Bogdanovich's account of Smurov, in his letter to Robrtovich, labels him a member of "sexual lefties" who frequently break the law and "a thief in the ugliest sense of the word," a kleptomaniac. Gretchen (or Hilda) takes Smurov as a silly boyfriend whom she dupes into wearing a stolen tie. Weinstock's description of Smurov is "an adventurer," "a Don Juan, a Casanova," "a double or triple agent," "a very odd character," "a man knit of incomplete intimations, a man with a secret hidden in him". Evgenia considers him as a shy, sensitive, and young man, lacking experience with people. Marianna's Smurov is a "brutal and brilliant officer of the White Army, the kind that went around stringing people up right and left". And finally, Kashmarin develops "yet another image" of Smurov. Each character preserves an exclusive idea of Smurov. These reflections, emitted from "the many-faceted Russian intelligentsia", are parts of the "classification of Smurovian masks" - which are still subject to change in future due to the "branching structure" and the "wavering nature of life" (The Eye, 1990, Kindle). Hence, Joann Karges' remarks on the theme of systematics in The Eye. The narrator-Smurov hunts for the "specification" of and "identification" with the real Smurov from which only its "paratypes" exist (1985, pp. 65-66). This butterfly metaphor suggests that an original source which once existed is now lost (Rutledge, 2011, p. 97). According to Smurov himself,

I do not exist: there exist but the thousands of mirrors that reflect me. With every acquaintance I make, the population of phantoms resembling me increases. Somewhere they live, somewhere they multiply. I alone do not exist. Smurov, however, will live on for a long time. [...] and so my name and my ghost will appear fleetingly here and there for some time still. Then will come the end. (The Eye,1990)

Therefore, there are myriad versions of Smurov which are radiated from others' eyes as they blink him into existence. However, as others close their eyes, their versions of Smurov are still replaced by other ones. In Rylkova's view (2002), Nabokov's story recounts "Smurov's learning to cope with his scattered personality" (p. 48). Nabokov's story at the same time highlights the fact that identity is like a "chameleon" in continual adjustments to environmental changes (Mohanu, 2001, p. 81).The synoptical network of power relations between Smurov and others emphasizes the inevitability of such state of living. This does not mean that he is bound to be defined by others for his existence; numerous labels expose him to a realm of definitions the transiency of 
which resists absolute definition. Such resistance is the inevitable outcome of relations any man may have with others. In fact, pursuing himself in the third person and through his reflections in others, the "I" of the story hesitates "between megalomania and an inferiority complex" (Grishakova, 2012, p. 172). And thus he finds himself into a new state of living.

\section{The Care of the Self and Parrhesia}

In its self-discovering activities, the self can take two forms: one form is a subject who actively seeks something, while the other form is an object that is itself passively sought. This process is the same as the "care of the self" which results in a subjectivity as "the concrete form of activity that defines the relationship of the self to itself" (McGushin, 2011, p. 129). That is because "subjectivity, as a dynamic, active relationship" can take on several different shapes (Foucault, 1996, p. 440). Looking at the self, one may ontologically wonder whether his/her existence is a total "material substance" or "an immaterial" one, and whether it is in a symbiotic relation to the body for worldly perception and action (McGushin, 2011, p. 130). Even if one's true self ever exists, it is still bound to the body until the body lives. The idea of "a true self within" behind the mask of reality conveys a specific relationship of the self to itself. Foucault calls this new subjectivity "hermeneutic" or "confessional", standing respectively for the "activities of self-interpretation and self-expression" (p. 134). In other words, the individual is then to interpret his own self, to explain it to himself, in order to most truly recognize his self and escape identity crisis. These activities do not bespeak an inner truth; rather, they are activities toward becoming a different person with new relations towards the self, a taking "care of the self", an "aesthetics of the self". In Foucault's view (2001),

For one does not have to take up a position or role towards oneself as that of a judge pronouncing a verdict. One can comport oneself towards oneself in the role of a technician, of a craftsman, of an artist, who from time to time stops working, examines what he is doing, reminds himself of the rules of his art, and compares these rules with what he has achieved thus far. (p. 166)

Afterwards a new discipline is born. In Foucault view, discipline is not surveillance but "the regulation of behavior or attitude" after surveillance (Mathieson, 1997, p. 228). By realizing the monoptical and synoptical relations of power, by having new surveying outlooks towards human relations, the narratorSmurov finally controls himself. It is manifested in the final merging of the narrator and Smurov and his final statement that he decides not to care for whatever reflection his existence may create in others, since identity will not remain fixed. As Foucault says, in the modern era, the human body enters "a machinery power that explores it, breaks it down and rearranges it" ad infinitum (1979, p. 138). Acting and behaving differently in different conditions require constant self-sacrificing in order to deal with the dynamic state of human affairs. This is what Smurov undertakes by shooting his former being. This act of freedom is a technique of the "care of the self" and the transformation necessary for subjectivity. Foucault considers freedom as "a matter of experimentation"; entering "a space of concrete freedom" is not to recognize who we are as established personalities but to try the different "possible transformations" that life can offer us (1990, p. 36). Freedom is therefore "a praxis", a way of dealing with ourselves, others, and the world (Mendieta, 2011, p. 112).

In more details, freedom as such is achieved through parrhesia and the "care of the self." Freedom is a "creative" process, which results not from ultimate submission to external powers but from generating power over oneself, a power which one is able to exercise over others as well (p. 116). In this sense, freedom is not achieved in isolation but only results from the power relations we have with others, something that initially requires us to be true to ourselves. As such, the individual stands in a parrhesiastic relationship with himself; that is, in a position to be truthful to himself. Although parrhesia typically stands for fearless speech and the parrhesiast is someone who critically and frankly speaks the truth before the truth-mongers (Foucault, 2001, p. 11), a parrhesiastic attitude is not exclusive to someone of this type. Being true to oneself and having a critical attitude against the absolute condition of something is parrhesiastic enough. "Being courageous enough to disclose the truth about oneself' away from self-delusion is parrhesiastic (p. 143).As Stone points out, the final stage in the use of parrhesia is in "one's private life" and "one's personal relationships." Smurov tries to watch over himself, which is a parrhesiastic act of self-caring. We hear Nabokov's narrator saying, "Ever since the shot - that shot which, in my opinion, had been fatal - I had observed myself with curiosity instead of sympathy, and my painful past - before the shotwas now foreign to me " (The Eye,1990). Initially punishing himself through suicide because of his past life, Smurov now decides to take care of himself. He decides to be on guard, both monoptically and synoptically, over his actions. The panoptic tower of surveillance is thus watching him, inside and outside. 
So, he experiences a transition from "the torture of the body to the transformation of the soul" (Mathieson, 1997, p. 216). His body is no more to suffer while his soul is the object of constant metamorphoses. Reading Nabokov's novella, we are, as Foucault says, "in the panoptical machine, invested by its effects of power, which we bring to ourselves since we are a part of its mechanism" (1979, p. 217).Therefore, due to the socio-historical nature of subjectivity, Foucault emphasizes that it is always possible to experience a being or beings other than what we presently are, the consequence of which is the practice of freedom.

\section{CONCLUSION}

Whether in agony before his ultimate physical death in the case of his self-shooting, or even in his pains when he imagines life in a purgatorial condition after his suicidal attempt, Nabokov's protagonist in The Eye is reborn into a new state of living in which he experiences himself anew. Initially bound by temporality, Smurov is liberated from his primary self through his subconscious mind. He is reborn into beings which are often unstuck in time. As a Russian émigré, Smurov is under historically given constraints which are intensified by his initial sense of absurdity. His self-discovery, which begins with an act of suicide, leads to the recognition of the fact that his identity is made of an amalgam of images radiating from himself, just to be reflected from and deciphered by others. This fact brings him a state of happiness at the end of the novella and after all his torturing wonderings. By experiencing himself through a thirdperson perspective, Smurov disciplines himself through self-caring and panopticism, so as to watch over himself for self-recognition. His parrhesiastic relation to himself, his doppelganger's monoptic eye, and others' synoptic eyes of surveillance begin and continue to watch him and mirror back to him the portrait he has shown them. And each portrait, as reflected back to Smurov, adds to his developing self. As such, Smurov develops a dynamic relationship with himself which establishes his new and selfconscious state of being. At the end of the novella, when the narrator and Smurov become one, he stoically announces his self-discovery by acknowledging the importance of the never-blinking eye of surveillance in the shaping of his identity and his tolerance over any sarcasm.

Having punished himself as a result of feeling shame before others, Smurov now disciplines himself, as in a Panopticon, and tries to be on guard both monoptically and synoptically over his deeds thereafter. The changes which he experiences reflect both his critical attitude towards his prior state of living, because of which he punishes himself, and a tendency to selfcaring attitudes towards life and his identity. $\mathrm{He}$ observes that true happiness is relative, and that he shall, for a more sophisticated state of living, fundamentally keep in balance the relations of power between himself and others. Inherent in both monopticism and synopticism is a centrality of power which helps the observer with accounts of his situation. As versions of panopticism, these two are in fact the inevitable participants in the formation of one's identity towards self-discovery. Smurov's attempt at self-discovery is a manifestation of his attempt to be truthful to himself, thus fulfilling the concept of the parrhesia. And all these together highlight the power relations embedded in the formation and dynamicity of identity.

\section{REFERENCES}

Boyd, B. (1990). Vladimir Nabokov: the Russian years. Princeton: Princeton University Press.

Carrette, J. (2000). Foucault and religion. London: Routledge.

Connolly, J. W. (1991). Madness and doubling: from Dostoevsky's The Double to Nabokov's The Eye. Russian Literature Triquarterly, 24, 129-39.

Connolly, J. W. (1999). Nabokov's (re)visions of Dostoevsky. In J. W. Connolly (Ed.), Nabokov and his fiction: New perspectives (pp. 141-157). Cambridge: Cambridge University Press.

Dolinin, A. (2005). Nabokov as a Russian writer. In J. W. Connolly (Ed.), Cambridge companion to Nabokov (pp. 49-64). Cambridge: Cambridge University Press.

Flower, D. N. (1987 Spring). Nabokov's private eye. The Hudson Review, 40(1), 165-171.

Foster Jr., J. B. (1993). Nabokov's art of memory and European modernism. Princeton: Princeton University Press.

Foucault, M. (1990). Critical theory/intellectual history. In L. Kritzman (Ed.), Michel Foucault: politics, philosophy, culture: Interviews and other writings 1977-1984 (pp. 17-46), translated by A. Sheridan \& others. London: Routledge.

Foucault, M. (1979). Discipline and punish: the birth of the prison, translated by A. Sheridan. New York: Vintage.

Foucault, M. (1997). Ethics, Subjectivity and truth. Paul Robinow (Ed); translated by Robert Hurley $\&$ others. New York: The New Press.

Foucault, M. (2001). Fearless speech. (J. Pearson, Ed.). Los Angeles: Semiotext(e).

Foucault, M. (1996). The ethics of the concern for the self as a practice of freedom. In S. Lotringer (Ed.), Foucault live: collected interviews 19611984 (pp. 432-449). New York: Semiotext(e). 
Four to Doomsday. (1982). Dr. who: Season 19, episodes 5-8. [DVD]. (Terence Dudley, Writ). (John Black, Dir.). BBC One.

Govedić, N. (2001). When the eye refuse to blind itself: Nabokov's writings on literature. Slavica Tergestina, 9, 235-264.

Grishakova, M. (2012). The models of space, time and vision in V. Nabokov's fiction: Narrative strategies and cultural frames. Tartu: Tartu University Press.

Jacobs, K. (2001). The eye's mind: Literary modernism and visual culture. Ithaca: Cornell University Press.

Johnson, D. B. (1985). The books reflected in Nabokov's Eye. Slavic and East European Journal, 29.4, 393-404.

Johnson, D. B. (1997). The butterfly in Nabokov's Eye. The Eye Nabokov Studies, 4, 1-14.

Johnson, D. B. (1995). The Eye. In V. E. Alexandrov (Ed.), The Garland Companion to Vladimir Nabokov (pp. 130-135). New York: Garland.

Karges, J. (1985). Nabokov's lepidoptera: Genres and genera. Ann Arbor: Ardis.

Mathieson, T. (1997). The viewer society: Michel Foucault's 'panopticon' revisited. Theoretical Criminology: An International Journal, 1(2), 215-232.

McGushin, E. (2011). Foucault's theory and practice of subjectivity. In Diana Taylor (Ed.), Michel Foucault: Key concepts (pp. 127-142). Durham: Acumen.

Mendieta, E. (2011). The practice of freedom. In Diana Taylor (Ed.), Michel Foucault: Key concepts (pp. 111-124). Durham: Acumen.

Mohanu, F. (2001). Aspects of identity in Vladimir Nabokov's novels. Dialogos,3, 80-82.

Nabokov, V. (1990). The Eye (Kindle Edition). New York: Vantage Books.
O'Day, A. (2011, April 8). "I spy, with my little eye": surveillance and space in Doctor Who. The Politics of Television Space' Symposium. University of Leicester. Retrieved from http://www. hrvt.net/andrewoday/space.htm.

Reber, A. S. (1985). Dictionary of psychology. London: Penguin Books.

Rutledge, D. (2011). Nabokov's permanent mystery: the expression of metaphysics in his work. London: McFarland \& Company Inc. Publishers.

Rylkova, G. (2002). Okrylyonnyy Soglyadatay- the winged eavesdropper: Nabokov and Kuzmin. In D. H. J. Larmour (Ed.), Discourse and ideology in Nabokov's prose (pp. 43-58). London: Routledge.

Schaeffer, S. F. (1972). The editing blinks of Vladimir Nabokov's The Eye. The University of Windsor Review, 8.1, 5-30.

Stone, B.E. (2011). Subjectivity and truth. In Dianna Taylor (Ed.), Michel Foucault: Key concepts (pp. 143-157). Durham: Acumen.

Straumann, B. (2008). Figurations of exile in Hitchcock and Nabokov. Edinburgh: Edinburgh University Press.

Taylor, D. (Ed.). (2011). Michel Foucault: Key concepts. Durham: Acumen.

Toker, L. (1999). "The dead are good mixers": Nabokov's versions of individualism. In J. W. Connolly (Ed.), Nabokov and his fiction: New perspectives (pp. 92-108). Cambridge: Cambridge University Press.

Vintges, K. (2011). Freedom and spirituality. In Dianna Taylor (Ed.), Michel Foucault: Key concepts (pp. 99-110). Dyrham: Acumen.

Wyllie, B. (2010). Vladimir Nabokov. London: Reaktion Books Ltd. 